\title{
Claudin-18 Isoform A2
}

National Cancer Institute

\section{Source}

National Cancer Institute. Claudin-18 Isoform A2. NCI Thesaurus. Code C150412.

Claudin-18 isoform A2 (261 aa, $\sim 28 \mathrm{kDa}$ ) is encoded by the human CLDN18 gene. This protein is involved in tight junction formation in the epithelium of the gastric mucosa. 